\title{
Isolation and Purification of Antibacterial Components in Cortex Phellodendri
}

\author{
Jung-Bae Kim, Woon-Seob Shin", Young-In Kwon ${ }^{* *}$ and ${ }^{\dagger}$ Byung-Ho Bang ${ }^{* * *}$ \\ Dept. of Food Nutrition and Cookery, Sangji Youngseo College, Wonju 220-713, Korea \\ *Dept. of Microbiology, Kwandong University College of Medicine, Kangnung 210-701, Korea \\ ${ }^{* *}$ Dept. of Food and Nutrition, Hannam University, Daejeon 305-811, Korea \\ ${ }^{* * *}$ Dept. of Food and Nutrition Science, Eulji University, Seongnam 461-713, Korea \\ 황백나무로부터 항균성분의 분리 및 정제 \\ 김중배 · 신운섭" · 권영인"* + 방병호 ${ }^{* * *}$ \\ 상지영서대학교 식품영양조리학과, "관동대학교 의과대학 미생물학교실, \\ "*한남대학교 식품영양학과, "**을지대학교 식품영양학과

\section{국문요약}

황백 껍질은 황벽나무(Phellodendron amurense)의 건조된 수피로부터 얻어진다. 이 수피는 한국의 전통 한약제로서, 설사, 황달, 무릎과 발의 통증, 요도관 및 피부 감염증에 폭넓게 사용되어 왔다. 본 연구는 황벽나무의 메탄올 추출액 으로부터 항균성 화합물 분리를 위해 $\mathrm{CPC}$ 방법으로 효과적으로 수행하였다. 두 용매의 CPC 최적조성은 n-butanol: acetic acid:water(4:1:5 v/v/v)이었다. 이동상의 유속은 $1,000 \mathrm{rpm}$ 회전력에서 상승법으로 분당 $3 \mathrm{ml}$ 속도로 전개시켰다. $\mathrm{CPC}$ 에서 분리된 분획분은 prep-HPLC로 정제하였다. 분리된 palmatine은 ${ }^{1} \mathrm{H},{ }^{13} \mathrm{C}-\mathrm{NMR}, \mathrm{ESI}-\mathrm{MS}$ 데이터 분석으로 확인 하였다.

Key words: CPC, HPLC, palmatine, Cortex Phellodendri

\section{INTRODUCTION}

Many efforts have been made to discover new antimicrobial compounds from various natural sources such as soil, microorganisms, animals and plants. One such resource is folk medicines and their systematic screening can result in the discovery of novel effective compounds. We have intensively searched for new effective medicines among natural products, particularly oriental herbal medicines (OHM). OHM have played an important role in clinical therapy in Korea for thousands of years and have been utilized widely in the healthcare system. They have been the major foundation for preventing and treating many diseases for centuries.

Cortex Phellodendri (CP) is derived from the dried bark of
Phellodendron amurense. It has been widely used as a drug in traditional Korean medicine for treating diarrhea, jaundice, swelling pains in the knees and feet, urinary tract infections and infections of the body surface (Lee et al. 2005; Min et al. 2008).

The diverse geographical sources of this plant result in large variations in alkaloid content such as berberine, jatrorrhizine, and palmatine, which are quite different from each other. Thus, it is necessary to determine the species of $\mathrm{CP}$ as well as the actual total alkaloid content used in the raw material because of different doses for different medical uses (Chen et al. 2008).

Advances in biological and separation sciences have facilitated the transition between the use of crude herbal medicines and the exploitation of purified active herbal constituents (Chen et

\footnotetext{
${ }^{\dagger}$ Corresponding author: Byung-Ho Bang, Dept. of Food and Nutrition Science, Eulji University, Seongnam 461-713, Korea. Tel: +82-31-740-7132, Fax: +82-31-740-7370, E-mail: gunnerbh@eulji.ac.kr
} 
al. 2010; Li et al. 2009).

Many analytical methods have been utilized to study $\mathrm{CP}$, such as thin-layer chromatography, silica gel and octadecyl (C18) gel column chromatography. Centrifugal partition chromatography (CPC) is a liquid-liquid partition chromatography technique that does not use a solid support matrix, resulting in no irreversible adsorption of the sample onto the solid matrix and less peak tailing and contamination (Poucault AP 1994). High selectivity is obtained by careful choosing the biphasic solvent system; thus, allowing separation of compounds with very similar structures. This method has been widely applied for preparative separation of various natural products such as alkaloids, flavonoids and hydroxyanthraquinones (Yin et al. 2009; Zhang et al. 2011). In this study, the antibacterial activities of methanol extracts from 11 kinds of OHMs were screened in vitro using the plate disk assay method. Among them, The methanol extracts of $\mathrm{CP}$ (stem of Phellodendron amurense) showed remarkably potent antibacterial activities.

We report the results of screening for antibacterial activities in a $\mathrm{CP}$ extract. Isolation of the active constituents of $\mathrm{CP}$ was performed by CPC.

\section{MATERIALS AND METHODS}

\section{Apparatus}

Preparative CPC was performed using a LLB-M high performance CPC (Sanki Instruments Ltd, Tokyo, Japan). The CPC system was equipped with a 321 pump (Gilson, Middleton, WI, USA) and a UV-VIS detector (S-3702 Soma, Sōma City, Japan), a fraction collector (FC-203B, Gilson) and a $1 \mathrm{~m} \ell$ sample loop. The analytical high performance liquid chromatography (HPLC) system consisted of a binary Gilson 305 pump, a UV detector (M720 Youngin, Seoul, South Korea) and a 506C interface module (Gilson). Nuclear magnetic resonance (NMR) (300 MHz for ${ }^{1} \mathrm{H}-\mathrm{NMR}$ and $225 \mathrm{MHz}{ }^{13} \mathrm{C} \mathrm{NMR}$ ) spectra were measured in methanol-D4 (MeOD, 99.9\%) using a Bruker Biospin DSX-300 spectrophotometer (Billerica, MA, USA) and mass spectra and the molecular weights of the compound were measured by positive electrospray ionization mass spectroscopy (ESI-MS) (Applied Biosystems, Foster City, CA, USA) at the Korea Basic Science Institute (Daejeon, South Korea).

\section{Crude Extract Sample Preparation}

Dried CP and OHMs were obtained from a Wonju Oriental medicine market (Kwangwon Province, Korea). Dried CP (400 g) was extracted with $2 \ell$ of $80 \%$ methanol for $48 \mathrm{hr}$. The extract was concentrated in a rotary vacuum evaporator to obtain the crude extract (40 g). The extract was dissolved in $100 \mathrm{~m} \ell$ water and extracted with butanol. A portion of the residue obtained after evaporation of the butanol was dissolved as the lower layer in the CPC solvent system.

\section{Antimicrobial Assay}

Antibacterial activities were assessed using the disc diffusion method (Seneviratne et al. 2007). The test bacteria was Staphylococcus aureus KCTC 1621. OHMs (5 g) were extracted with $100 \mathrm{ml} 80 \%$ methanol in an ultrasonic apparatus at room temperature and concentrated in vacuo. The OHMs were dissolved in sterilized distilled water to achieve a final volume of $1 \mathrm{~m} \ell(10 \mathrm{mg} / \mathrm{m} \ell)$ Muelller-Hilton agar plates were prepared, and the inocula were seeded by the spread plate method. Sterile discs (diameter, $7 \mathrm{~mm}$ ) were loaded with $200 \mu$ of $\mathrm{OHM}$ methanol extract and introduced in sterile medium with the test organism. The plates were incubated at $37^{\circ} \mathrm{C}$ for $24 \mathrm{hrs}$. Activity was evaluated by measuring the diameter of the inhibition zone.

\section{CPC Separation Procedure}

The two-phase solvent system was composed of n-butanol: water (1:1). The solvent mixture was mixed vigorously in a separatory funnel and equilibrated at room temperature to obtain the upper and lower phases. The lower phase (stationary phase or aqueous phase) of the two-phase solvent system was pumped into partition cells in the ascending mode at a flow rate of $15 \mathrm{~m} \ell / \mathrm{min}$ without rotation. When all cells were completely filled with the stationary phase, the upper phase was pumped at a flow rate of $3 \mathrm{~m} / / \mathrm{min}$ at a rotor speed of $1,000 \mathrm{rpm}$. After equilibrium was established, as indicated by the glow of the mobile phase solvent from the CPC system outlet, a water sample solution was injected into the $\mathrm{CPC}$ system (Poucault AP. 1994). The eluate was monitored at 254 $\mathrm{nm}$ and each fraction was collected in an $10 \mathrm{~m} \ell /$ tube with a Gilson FC 203B fraction collector.

\section{HPLC Analysis}

The CPC-separated fraction and crude extract were analyzed by HPLC. A J'sphere ODS-H80 column (4 $\mu$ m particle size, $120 \AA$, 150×4.6 mm, YMC Co. Ltd., Tokyo, Japan) was used. The mobile phase was composed of $25 \%$ acetonitrile in 
$0.1 \%$ aqueous trifluoroacetic acid (TFA) in a gradient system. The flow rate was $1 \mathrm{~m} / / \mathrm{min}$ with UV absorbance detection at $280 \mathrm{~nm}$. Preparative HPLC was performed using a reversed phase column (Gemini $5 \mu \mathrm{m}, 110 \AA, 100 \times 21.28$ $\mathrm{mm}$, Phenomenex, Torrance, CA, USA) with $25 \%$ acetonitrile in $0.1 \%$ aqueous TFA at a flow rate of $4 \mathrm{ml} / \mathrm{min}$ and monitoring at $321 \mathrm{~nm}$.

\section{RESULTS AND DISCUSSION}

\section{Screening and Antibacterial Activities}

Methanol extracts of roots, fruit, leaves, radix and stems of 11 species of $\mathrm{OHM}$ were examined for antibacterial activity. Staphylococcus aureus KTCC 1621 was used to assess the growth inhibitory effects by the paper disc diffusion method. CP showed the highest inhibitory activity against $S$. aureus, followed by Rheum palmatum, Glycyrrhiza uralensis, Schisandra chinensis, Scutellaria baicalensis, Cornus officinalis and Cnidium officinale (Table 1).

\section{Choice of Two-phase Solvent System}

Purification procedures were carried out by CPC and preparatory HPLC to identify the $\mathrm{CP}$ antibacterial compounds. The $80 \%$ methanol extract of $\mathrm{CP}$ was concentrated in vacuo at $50^{\circ} \mathrm{C}$, and the mother liquor was extracted with butanol. A portion of the residue obtained after evaporating the butanol was dissolved

Table 1. Antimicrobial activities of methanol extracts of oriental herbal medicines

\begin{tabular}{lc}
\hline \hline Name of herbal medicines & Inhibition zone $(\mathrm{mm})$ \\
\hline Angelica tenuissima & 3 \\
Cnidium officinale & 5 \\
Cornus officinalis & 7 \\
Glycyrrhiza uralensis & 10 \\
Phellodendron amurense & 15 \\
Rheum palmatum & 11 \\
Rubus coreanus & 4 \\
Schisandra chinensis & 9 \\
Scutellaria baicalensis & 8 \\
Eucommiae cortex & 5 \\
Patrinia scabiosaefolia & 3 \\
\hline
\end{tabular}

An antibacterial activity was assessed using the disc diffusion method.

The tested bacterium was Staphylococcus aureus KCTC 1621.

$$
\begin{aligned}
& \text { Dried Cortex Phellodendri (CP, } 200 \mathrm{~g}) \\
& \qquad \leftarrow \text { extracted } 2 \ell \quad 80 \% \text { methanol }
\end{aligned}
$$

Evaporation

$$
\downarrow \leftarrow \text { extracted } 100 \mathrm{~m} \ell \text { n-butanol }
$$

Evaporation (28 g)

$$
\begin{aligned}
& \text { Preparative CPC } \\
& \qquad \leftarrow \text { n-butanol/ water (1:1), } \\
& \downarrow \quad 3 \mathrm{~m} \ell / \mathrm{min}, 1000 \mathrm{rpm}
\end{aligned}
$$

Evaporation (79.8 mg)

Prep-HPLC

$\downarrow \leftarrow$ eluted with $30 \%$ acetonitrile

Compounds IIa (pale yellow powder, $21.5 \mathrm{mg}$ )

Fig. 1. Purification scheme of the dried Cortex Phellodendri methanol extract.

in the lower layer of the solvent system and then pumped into the column at $3 \mathrm{ml} / \mathrm{min}$. The crude methanol extract was purified by the procedure summarized in Fig. 1.

A successful separation by CPC depends on selecting an optimum two-phase solvent system with an ideal partition coefficient $(K)$ range for the target compound of 0.2 and 2 (Kim et al. 2006; Kim et al. 2007; Osamu et al. 2008; Kim et al. 2010; Kim JB 2011). If $K$ value is higher than 10, the eluted peaks are broad and excessive mobile phase volume and time were required to complete a CPC run. The compounds do not separate under $K$ conditions $<0.2$. Several two-phase solvent systems were tested and their $K$ values were measured. A twophase solvent system composed of n-butanol: acetic acid: water showed appropriate $K$ values. As a result of the partitioning behavior of peaks IIa, the two-solvent system composed of n-butanol: acetic acid: water $(4: 1: 5 \mathrm{v} / \mathrm{v} / \mathrm{v})$ resulted in a favorable partitioning value of $K=1.05$, between the two layers (Table 2).

Table 2. The $K$ (partition coefficient) values of palmatine in the two-phase solvent system

\begin{tabular}{lcc}
\hline \multicolumn{1}{c}{ Solvent system } & Volume ratio & $K$ value \\
\hline n-Butanol : water & $5: 5$ & 0.67 \\
n-Butanol : iso-butanol : water & $4: 1: 5$ & 0.33 \\
n-Butanol : acetic acid : water & $4: 1: 5$ & 1.05 \\
\hline
\end{tabular}




\section{CPC Separation}

The dried CP methanol extract was separated and purified by CPC with a n-butanol: acetic acid: water (4:1:5) solvent system. As shown in Fig. 2, the fractions were collected for

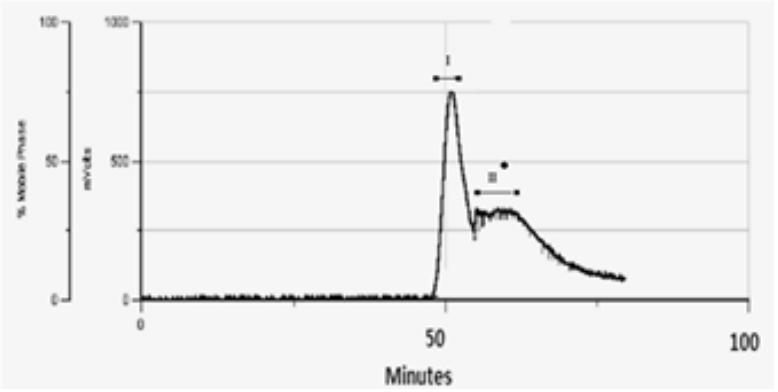

Fig. 2. Preparative centrifugal partition chromatography (CPC) separation of the methanol Cortex Phellodendri extracts. Solvent system: n-butanol/acetic acid/water (4:1:5), flow rate $3 \mathrm{ml} / \mathrm{min}$; rotation speed, $1,000 \mathrm{rpm}$; detection, $280 \mathrm{~nm}$
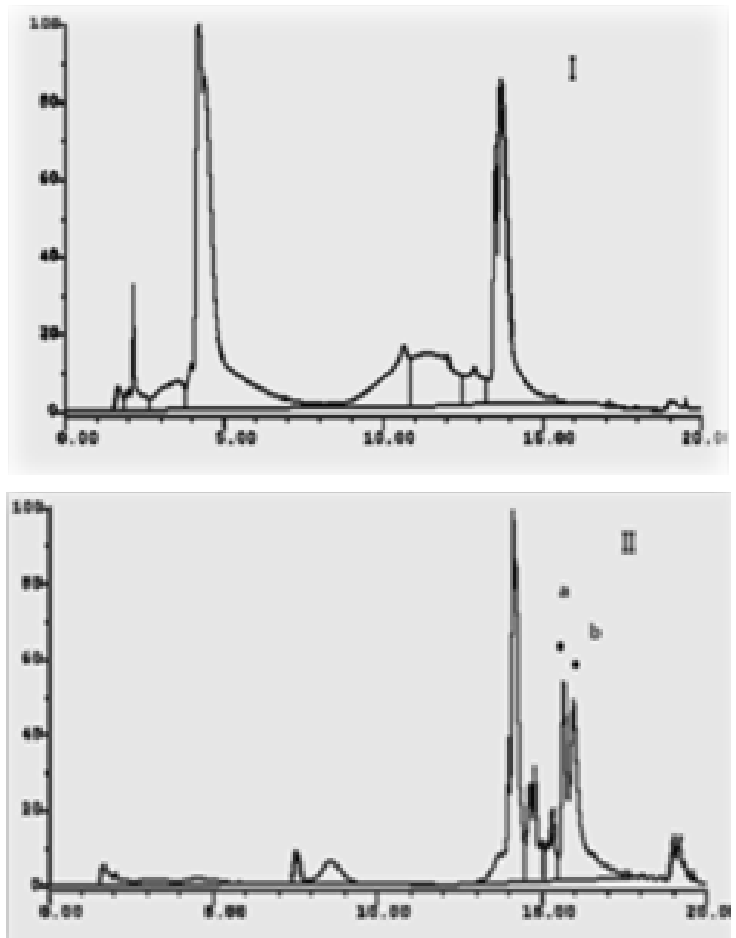

Fig. 3. Centrifugal partition chromatography (CPC) chromatogram of a Cortex Phellodendri methanol extract together with high performance liquid chromatography (HPLC) chromatograms of CPC peak fractions I and II. Column, J'sphere ODS-H80, $4 \mu \mathrm{m}$ particle size, $120 \AA, 150 \times 4.6 \mathrm{~mm}$, YMC Co. Ltd.; elution solvent, $0 \sim 3 \mathrm{~min} 15 \%$ acetonitrile, $3 \sim 10 \mathrm{~min}$ $15 \sim 50 \%$ acetonitrile in $0.1 \%$ aqueous trifluoroacetic acid (TFA) in a gradient system. Elution time, $20 \mathrm{~min}$; detection, $280 \mathrm{~nm}$ about $80 \mathrm{~min}$ and were grouped as I and II.

The separated fractions were analyzed by HPLC and the results indicated that the extract contained several compounds including peaks IIa and IIb (retention times, 15.6 and $16.2 \mathrm{~min}$, respectively) and some unknown compounds (Yang et al. 2010). The peak IIb is in the process of structural analysis. Fig. 3 shows typical HPLC profiles of the CPC separated fractions. Fig. 3 shows that purification of IIa and IIb was achieved in only $80 \mathrm{~min}$.

\section{Structural Elucidation of Peaks Ila}

The structural identification of peak fractions IIa in Fig. 4 was performed by ${ }^{1} \mathrm{H}$ NMR and ${ }^{13} \mathrm{C} \mathrm{NMR}$.

The area under the peaks showed that the resonances at $\delta$ $3.79,3.84,3.97$, and $4.07 \mathrm{ppm}$ corresponded to three $\left(-\mathrm{CH}_{3}\right)$ protons, whereas those at $\delta 3.06$ and 4.69 ppm corresponded to two protons $\left(-\mathrm{CH}_{2}\right)$. All other resonances corresponded to one proton $(-\mathrm{CH})$ (Tripathi et al. 2008; Li et al. 2009).

When these ${ }^{1} \mathrm{H}$ NMR, ${ }^{13} \mathrm{C}$ NMR, and ESI-MS data were compared to those reported in the literature (Lee et al. 2005;

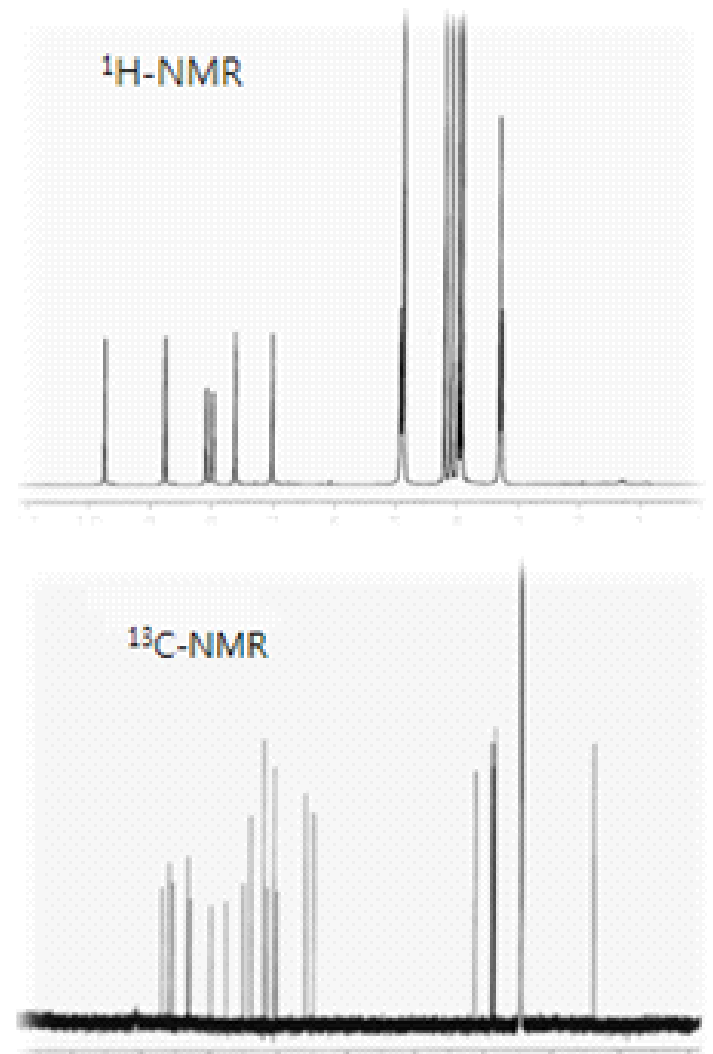

Fig. 4. ${ }^{1} \mathrm{H}-$ Nuclear magnetic resonance (NMR) and ${ }^{13} \mathrm{C}-\mathrm{NMR}$ spectra of peak IIa. 


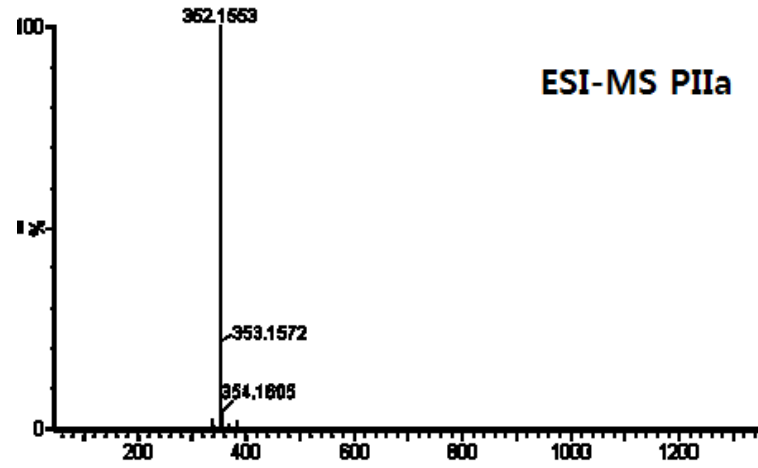

Fig. 6. Electrospray ionization mass spectroscopy(ESI-MS) chromatograms of palmatine(IIa).

Palmatine: ESI-MS m/z: 352.1553( $\left.\mathrm{M}^{+}\right)$

${ }^{1}$ H-NMR (900 MHz, MeOD) $\delta: 9.78(1 \mathrm{H}, \mathrm{s}, \mathrm{H}-8), 8.88$ $(1 \mathrm{H}, \mathrm{s}, \mathrm{H}-13), 8.10(1 \mathrm{H}, \mathrm{d}, \mathrm{J}=8.0 \mathrm{~Hz}, \mathrm{H}-11), 8.00(1 \mathrm{H}$, d, J=8.0 Hz, H-12), 7.63 (1H, s, H-1), 7.03 (1H, s, H-4), $4.87(2 \mathrm{H}, \mathrm{m}, \mathrm{H}-6), 4.19\left(3 \mathrm{H}, \mathrm{s}, 9-\mathrm{OCH}_{3}\right), 4.08(3 \mathrm{H}, \mathrm{s}$, $\left.10-\mathrm{OCH}_{3}\right), 3.97\left(3 \mathrm{H}, \mathrm{s}, 2-\mathrm{OCH}_{3}\right), 3.92\left(3 \mathrm{H}, \mathrm{s}, 3-\mathrm{OCH}_{3}\right)$, $3.52(2 \mathrm{H}, \mathrm{m}, \mathrm{H}-5)$

${ }^{13} \mathbf{C}-\mathbf{N M R}\left(225 \mathrm{MHz}, \mathrm{CD}_{3} \mathrm{OD}\right) \quad \delta: 152.6 \quad(\mathrm{C}-3), 150.7$ (C-10), 149.7 (C-2), 145.2 (C-8), 144.5 (C-9), 138.6 (C-13a), 134.0 (C-12a), 128.9 (C-4a), 126.8 (C-12), 123.3 (C-11), 122.1 (C-13b), 120.1 (C-13), 119.3 (C-8a), 111.0 (C-4), 108.7 (C-1), $61.3\left(\mathrm{C}-9, \mathrm{OCH}_{3}\right), 56.1\left(\mathrm{C}-2, \mathrm{OCH}_{3}\right)$, $55.8\left(\mathrm{C}-3, \mathrm{OCH}_{3}\right), 55.4(\mathrm{C}-6), 26.6(\mathrm{C}-5)$

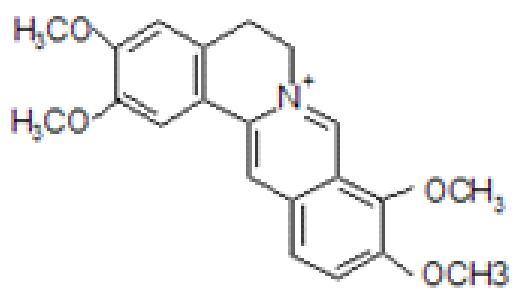

\section{Palmatine}

Fig. 7. The structures of palmatine(IIa).

Min et al. 2008; Deevanhxay et al. 2009; Hu et al. 2009; Ma et al. 2009) compounds IIa was identified as palmatine (Figs. 4 7).

\section{Summary}

Cortex Phellodendri (CP) is derived from the dried bark of Phellodendron amurense. It has been widely used as a drug in traditional Korea medicine for treating diarrhea, jaundice, swelling pains in the knees and feet, urinary tract infections and infections of the body surface. In this study, preparative centrifugal partition chromatography (CPC) was successfully carried out to separate antibacterial compounds from a CP methanol extract. The optimum two-phase CPC solvent system was composed of n-butanol: acetic acid: water $(4: 1: 5 \mathrm{v} / \mathrm{v} / \mathrm{v})$. The flow rate of the mobile phase was $3 \mathrm{~m} \ell / \mathrm{min}$ in ascending mode with rotation at 1,000 rpm. The CPC-separated fraction and purification procedures were carried out by preparatory HPLC. Palmatine weas identified by ${ }^{1} \mathrm{H},{ }^{13} \mathrm{C}$-nuclear magnetic resonance and electrospray ionizationmass spectroscopy spectral data analysis.

\section{References}

Chen J, Wang F, Liu J, Lee FSC, Wang X, Yang H. 2008. Analysis of alkaloids in Coptis chinesis Franch by accelerated solvent extraction combined with ultra performance liquid chromatographic analysis with photodiode array and tandem mass spectrometry detections. Analytica Chimica Acta 613: 184-195

Chen ML, Xian YF, Ip SP, Tsai SH, Yang JY, Cde CT. 2010. Chemical and biological differentiation of Cotex Phellodendri chinensis and Cortex Phellodendri amurensis. Planta Med $76: 1530-1535$

Deevanhxay P, Suzuki M, Maeshibu N, Li H, Tanaka K, Hirose S. 2009. Simultaneous characterization of quaternary alkaloids, 8-oxoprotoberberine alkaloids, and a steroid compound in Coscinium fenistratum by liquid chromatography hybrid ion time-of-flight mass spectrometry. J Pharm Biomed Anal $50: 413-425$

Hu YM, Su GH, Sze SCW, Ye W, Tong Y. 2010. Quality assessment of Cotex Phellodendri by high performance chromatography couled with electrospray ionization mass spectrometry. Biomed Chromatogr 24:438-453

Kim CY, Ahn MJ, Kim JW. 2006. Preparative isolation of mangiferin from Anemarrhena asphodeloides rhizomes by centrifugal partition chromatography. J Sep Sci 29:869-875

Kim CY, Kim JW. 2007. Preparative isolation and purification of geniposide from gardenia fruits by centrifugal partition chromatography. Phytochemical Analysis 18:115-117

Kim JB. 2011. Isolation of berberine from the rhizome of Coptis chinensis by centrifugal partition chromatography. Korean $J$ Food \& Nutr 24:617-621

Kim SM, Sang YF, Um BH. 2010. Preparative separation of 
chlorogenic acid by centrifugal partition chromatography from highbush blueberry leaves. Phytochemical Analysis 21:457-462

Lee JH, Lee BW, Moon YH, Yang MS, Jang KC, Park KH. 2005. Phytochemical constituents from the stem bark of Phellodendron amurense Rupr. Agric Chem Biotechnol 48: 93-96

Li CY, Tsai SI, Damu AG, Wu TS. 2009. A rapid and simple determination of protoberberine alkaloids in rhizoma Coptidis by $\mathrm{H}$ NMR and its application for quality control of commercial prescriptions. J Pharm Biomed Anal 49:12721276

Ma CH, Li ZX, Wang LX, Tang YH, Xiao HB, Huang CG. 2009. Identification of major alkaloids in rat urine by HPLC/DAD/ESI-MS/MS method following oral administration of Cortex Phellodendri decoction. Helvetica ACTA 92:379398

Min BS, Cho JS. 2008. Quantitive determination of protobeberine from the roots of Coptis chinensis. Natural Product Scinces 14:68-72

Osamu S, Kumi N, Setsuko S, Noriko K, Masanori K, Makoto I, Sanae o, Mitsuyasu U. 2008. Preparative separation of the saponin lancemaside A from Codonopsis lanceolate by centrifugal partition chromatography. Phytochemical Analysis 19:403-410
Poucault AP. 1994. Centrifugal Partition Chromatography. pp51239. Marcel Dekker

Seneviratne CJ, Wong RWK, Samaranayake LP. 2007. Potent anti-microbial activity of traditional Chinese medicine herbs against Candida species. Mycoses 51:30-34

Tripathi AN, Bisht K, Thankachan PP, Barthwao R. 2008. Quantum chemical and nuclear magnetic resonance spectral studies on molecular properties and electronic structure of palmatine molecule. J Mole Structure 878:139-148

Yang Q, Zhang F, Gao SH, Sun LA, Chen WS. 2010. Determination of bioactive compounds in Cortex Phellodendri by high performance liquid chromatography. J AOAC Inter 93: $855-861$

Yin L, Lu B, Lu Y, Xu L, Han X, Xu Y, Peng J, Sun C. 2009. Simultaneous determination of 11 active components in two well-known traditional Chinese medicines by HPLC coupled with diode array detection for quality control. J Pharm Biomed Anal 49:1101-1108

Zhang S, Wang W, Wang C. 2011. Preparative separation and purification of alkaloids from Rhizoma coptidis by high speed counter-current chromatography. Sep Purif Technol $76: 428-431$

$\begin{array}{lrlr}\text { 접 수 : 2013년 } & \text { 8월 } & \text { 1일 } \\ \text { 최종수정 : 2013년 } & \text { 9월 } & \text { 5일 } \\ \text { 채 택 : 2013년 } & \text { 9월 10일 }\end{array}$

